\title{
Gastrointestinal Stromal Tumor of the lleum Causing Mechanical Bowel Obstruction: A Case Report
}

\author{
Osman Erdoğan, ${ }^{1}$ Zafer Teke, ${ }^{1}$ Nihal Aykun, ${ }^{2}$ Orçun Yalav²

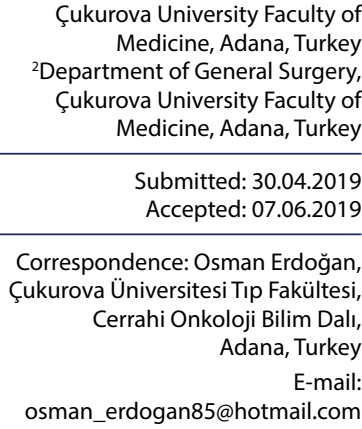

Submitted: 30.04 .2019

Accepted: 07.06.2019

Correspondence: Osman Erdoğan, Çukurova Üniversitesi Tıp Fakültesi, Cerrahi Onkoloji Bilim Dalı, Adana, Turkey \\ E-mail: \\ Keywords: Acute abdomen; \\ gastrointestinal stromal

\begin{abstract}
Gastrointestinal stromal tumors (GISTs) are submucosal tumors that stem from regions of the digestive tract, including esophagus, stomach, small intestine, colon and rectum. GISTs most commonly occur in the stomach $(50 \%-60 \%)$, the second most commonly in the small intestine $(20 \%-25 \%)$, and less frequently in the rectum $(5 \%)$. They are frequently diagnosed incidentally during radiological studies or endoscopic procedures performed to investigate gastrointestinal tract disease or to surgically treat an emergent condition, such as gastrointestinal hemorrhage, perforation, or obstruction. Surgery is the primary method to confirm the diagnosis of a GIST histopathologically. The primary purpose of surgical treatment in surgically resectable GISTs is to perform a resection procedure with clear surgical margins, leaving no visible tumors behind. In this case report, the clinical presentation, preoperative diagnosis and treatment of a GIST localized in the ileum were reviewed in the light of the literature.
\end{abstract} tumor; small bowel obstruction.

\section{INTRODUCTION}

Gastrointestinal stromal tumors (GISTs) are submucosal tumors that are originated from the digestive tract organs such as esophagus, stomach, small intestine, colon and rectum. ${ }^{[l]}$ GISTs are the most frequent mesenchymal tumors of the digestive tract which are originated from the interstitial Cajal cells localized on the intestinal wall and from neoplastic transformation of Cajal cell progenitors. ${ }^{[2]}$ The most common localization of GISTs is the stomach $(50 \%-60 \%)$, followed by the small intestines (20\%-25\%) and rectum (5\%). ${ }^{[3,4]}$ Approximately $50 \%$ of the GISTs have already had distant metastasis when they are diagnosed, with the liver and peritoneum being the most common regions for metastasis. Surgical intervention is the main method for histopathological diagnosis of GISTs. The primary purpose of surgical treatment in surgically resectable GISTs is to perform a resection with clear surgical margins, leaving no visible tumor. In this case report, we aimed to investigate the diagnosis and treatment of ileal GIST detected in a patient who was admitted to our emergency department, diagnosed with mechanical intestinal obstruction due to small intestinal tumor after evaluation and got surgical intervention.

\section{CASE REPORT}

A 65-year-old male patient was admitted to the emergency department of our hospital with the complaints of abdominal pain, vomiting, inability to pass gas and no bowel movement. In the physical examination; abdominal distention, tenderness, and rebound were found. The white blood cell count was $19.9 \times 10^{3} / \mu \mathrm{L}$, hemoglobin 10.3 $\mathrm{g} / \mathrm{dL}$ and hematocrit $32.8 \%$. Abdomino-pelvic computed tomography (CT) showed air-fluid levels in the ileo-jejunal loops, and a mass lesion with soft tissue density, approximately $67 \times 33 \mathrm{~mm}$ in size at the widest dimension and protruding in the lumen proximal to the ileal loops was identified (Fig. I). The patient was operated with the diag- 


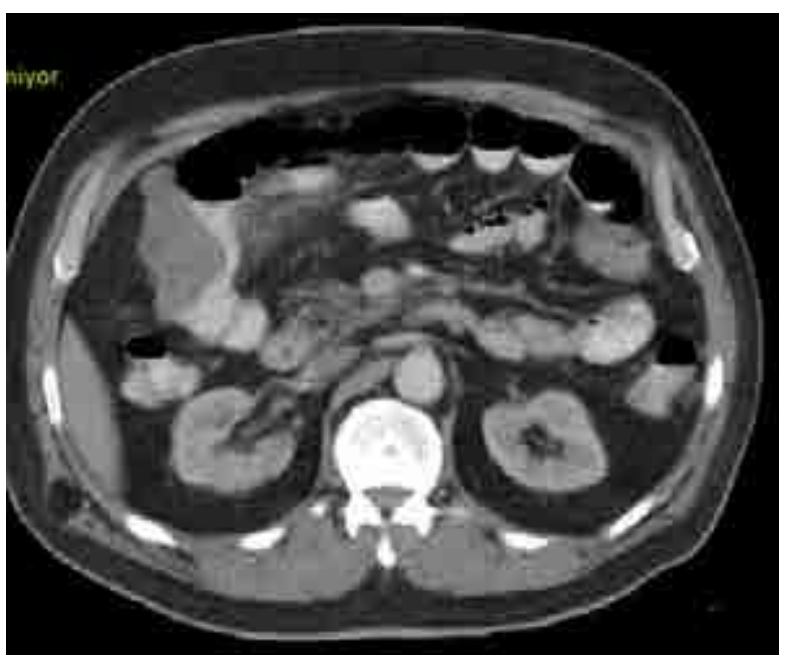

Figure 1. Computed tomography image of a heterogeneous contrasting mass that is thought to be in continuity with adjacent small intestinal loops.

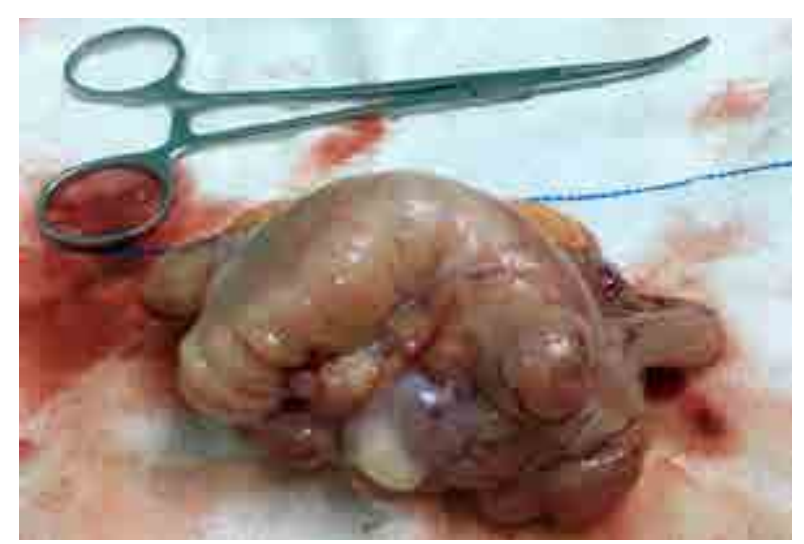

Figure 2. Total excised ileal GIST image.

nosis of acute abdomen due to mechanical ileus which was made with the help of examination and workup results. Some dilatation in the proximal of small intestines was observed. A tumoral mass of approximately $9 \times 4 \mathrm{~cm}$ with a hard consistency, protruding from the serosa, obstructing the lumen approximately $130 \mathrm{~cm}$ proximal to the ileocecal valve was detected, and total resection with clear surgical margins and side-to-side small intestinal anastomosis were performed (Fig. 2). Pathological examination revealed GIST, tumor with a maximum diameter of $7.5 \mathrm{~cm}$, had 10 mitosis in 50 high power fields and infiltrated into the mucosa. Surgical margins are clear. Immunohistochemical staining ratio was strongly diffuse positive for CD I 17 (c-Kit), DOGI, CD34, focal positive for SMA, and Ki-67 proliferation index was $6 \%-7 \%$. Cystic lysis regions have been observed in the tumor and no necrosis was identified. The patient was discharged on the postoperative day 7 without any complications with Imatinib treatment plan.

\section{DISCUSSION}

GISTs are mesenchymal tumors originating from interstitial Cajal cells that can develop from the esophagus to the internal anal sphincter throughout the gastrointestinal tract, as well as from the omentum, genitourinary system, portal vein and pancreas (extra-GIST). ${ }^{[2]}$ Although GISTs are generally seen after the age of 40 , they occur most commonly in the $60 \mathrm{~s} .{ }^{[5]}$ Our case was 65 years old and was in the age range reported in the literature. GIST is the most common mesenchymal tumor of the small intestines and covers $15 \%$ to $20 \%$ of all small intestinal tumors. ${ }^{[6,7]}$ When GISTs are studied in terms of the localization, it is mostly seen in the stomach (50\%-60\%), following with the small intestines $(20 \%-25 \%)$, rectum $(5 \%)$ and esophagus $(2 \%)$ in decreasing frequency. ${ }^{[8]}$ In our case, GIST was originated from the proximal ileum.

GISTs are usually asymptomatic when the tumor is $<2$ $\mathrm{cm}$ in diameter and are detected incidentally during a radiological imaging, endoscopic procedure, or surgical intervention done for another causes. GISTs that present with symptoms in patients may cause abdominal pain, dysphagia, dyspeptic complaints, digestive system bleeding, chronic anemia and abdominal mass according to the location of the tumor, but nonspecific to GIST. ${ }^{[9]}$ They may also present with signs requiring urgent medical or surgical intervention, such as intra-abdominal bleeding, massive gastrointestinal bleeding, gastrointestinal perforation, or mechanical bowel obstruction. Our patient had acute abdomen due to mechanical bowel obstruction and urgent laparotomy was required. In our case, GIST was extramural and obstructed the small intestinal lumen due to its size. Differential diagnosis of these tumors in preoperative period is not easy. This is mainly due to the lack of specificity of the symptoms and diagnostic methods used in patients. In our case, the presence of a mass causing dilatation of proximal ileal loops on abdomino-pelvic CT, which was taken for diagnosis in emergency conditions, was effective in making the decision for surgical intervention. In GISTs with a tumor diameter $>2 \mathrm{~cm}$, complete resection by surgical intervention should be considered in the first place. Periodic follow-up can be performed in GISTs with tumor diameter $<2 \mathrm{~cm}$. Endoscopic resection of GISTs in the stomach has been described in the literature, but the difficulties in obtaining a negative resection margin have not been sufficiently sought due to the risk of perforation in the stomach and the spread of the tumor after endoscopic intervention. ${ }^{[10]}$

Radiologic imaging and endoscopic examination methods can be used in patients with suspected GIST. Upright abdominal X-ray may show a non-specific soft tissue shadow and rarely calcifications. In barium upper and lower gastrointestinal series, it can be seen as an enlargement within the lumen or submucosal mass, while exophytic growth may show external compression effect on the adjacent organ or intestinal segment. ${ }^{\left[{ }^{I I}\right]}$ In addition, in abdominal ultrasonography, CT and magnetic resonance imaging methods, it may present as lesions with exophytic spread, which may also show luminal growth, mostly originating from the wall of the digestive system. ${ }^{\left[{ }^{22}\right]}$ In our case, CT showed a mass lesion with a soft tis- 
sue density of $67 \times 33 \mathrm{~mm}$ in the widest portion, protruding into the lumen proximal to the ileal loops. In the upper or lower gastrointestinal endoscopy, it may be seen as a submucosal lesion, however, in endosonography, as a hypoechoic lesion originating from muscularis propria. [II] [18F] Fluorodeoxyglucose (FDG) positron emission tomography (PET) is not a specific but sensitive method in the diagnosis of GISTs. It can be used to evaluate the spread of the disease and to monitor the metabolic activity of the tumor. It is also a useful method for detecting distant metastases because it provides the possibility for the imaging of whole body. ${ }^{\left[{ }^{\prime \prime}\right]}$

GISTs can be diagnosed more frequently with immunohistochemical staining methods by the extracellular membrane protein CD34, the tyrosine kinase receptor CDI I7, known as KIT, and DOGI protein. The underlying pathophysiology in terms of molecular carcinogenesis mechanisms is the excessive increase in the function of the tyrosine kinase receptor (KIT) in the cell membrane. In normal physiology, a monomeric tyrosine kinase receptor structure is present. When the extracellular ligand stem cell factor (SCF) binds to this receptor, dimerization occurs. ${ }^{[13]}$ This dimerization then leads to autophosphorylation, activating intracellular signaling pathways, leading to increased cell proliferation. ${ }^{[14]} \mathrm{KIT}$ gene mutation is most commonly found in exon- II. In 10\%-20\% of GISTs, KIT mutation is seen in exon- 9 and these tumors develop mostly in the small intestines. ${ }^{[15]}$ Platelet-derived growth factor receptor-alpha (PDGFR- $\alpha$ ) is another oncogene responsible for the activation of the intracellular phosphorylation cascade. PDGFR- $\alpha$ mutated GISTs are generally seen in KIT positive tumors. ${ }^{[16]}$ In GISTs, CDII7 is detected in $98 \%-100 \%$ of the cases. ${ }^{[2]}$ In GISTs, CD34 is found to be $70 \%-80 \%$, smooth muscle actin (SMA) $20 \%-40 \%$ and desmin $1 \%-2 \%$, while S-100 is found to be $5 \%$ positive. ${ }^{[2,6,14,17]}$ In the immunohistochemical panel of our case, staining ratio was strongly diffuse positive for CDII7 (c-KIT) and CD34, focal positive for SMA and negative for $\mathrm{S}-100$.

The diameter and number of mitosis in GISTs are the two most common parameters used to determine the prognosis. Bucher et al. ${ }^{[18]}$ described a useful staging system consists of 5 minor and 2 major criteria after surgical resection. Minor criteria are tumor size $\geq 5 \mathrm{~cm}$, mitotic index $\geq 5$, presence of necrosis, spread to surrounding tissue and MIB-I (Ki-67) index $>10 \%$. The presence of lymph node invasion and the presence of metastasis constitute the major criteria. If the tumor consists of less than 4 minor criteria, it is classified as low grade GIST, if it has 4 or 5 minor criteria and I major criterion, it is classified as high grade GIST. In our case, the tumor diameter was $7.5 \mathrm{~cm}$ and the mitosis index was 10/50 high power fields. Malignant course is seen in $40 \%$ of the GISTs with small intestine origin and $20 \%$ of the GISTs with gastric origin. ${ }^{[19]}$

Surgical resection is always the gold standard in the treatment of GISTs, with advances in medical oncologic therapies, and total excision is the most successful treatment modality today. A wide surgical margin and lymph node dissection are rarely required in GISTs. For this reason, laparoscopic surgery can generally be performed safely. [20] Patients who cannot have total resection due to distant metastases or locally advanced disease, and patients whose general condition is not suitable for surgery due to co-morbidities, or if surgical interventions with high morbidity and mortality are required; medical treatment might be preferred as a first line of therapy instead of surgery. There are three main objectives in GIST surgery; these are negative surgical margins, removal of the tumor without rupture, and complete resection of $\mathrm{RO}$ without any visible tumor, respectively. ${ }^{[2]}$ In histopathologically diagnosed patients with GIST, remission and regression of $50 \%-80 \%$ can be achieved with the use of imatinib mesylate, a tyrosine kinase inhibitor. ${ }^{[22]}$ In addition, imatinib mesylate has been used extensively in the first-line treatment of unresectable, recurrent or metastatic GISTs. ${ }^{[1,22,23]}$

\section{Conclusion}

As a result, total resection should be performed as much as possible in small intestine GISTs, which is a pathology present with nonspecific complaints and symptoms and usually requiring urgent surgical intervention. If it cannot be resected, a biopsy from this mass should be taken and sent to histopathological examination and medical treatment should be planned according to the result.

\section{Informed Consent}

Written informed consent was obtained from the patient for the publication of the case report and the accompanying images.

Peer-review

Internally peer-reviewed.

Authorship Contributions

Concept: O.E., Z.T.; Design: O.E., Z.T., N.A., O.Y.; Supervision: O.E., Z.T., N.A., O.Y.; Fundings: O.E., N.A., O.Y.; Materials: O.E., N.A., O.Y.; Data: O.E., N.A., O.Y.; Analysis: O.E., Z.T., N.A.; Literature search: O.E., Z.T.; Writing: O.E., Z.T.; Critical revision: O.E., Z.T., N.A.

Conflict of Interest

None declared.

\section{REFERENCES}

1. Tepeoğlu M, Özgün G, Tunca MZ, Tezcaner T, Özdemir BH. Gastrointestinal Stromal Tumors: A Clinicopathological and Immunohistochemical Study of 65 Cases. Turk Patoloji Derg 2018;34:20714. [CrossRef]

2. Duffaud F, Blay JY. Gastrointestinal stromal tumors: biology and treatment. Oncology 2003;65:187-97. [CrossRef]

3. Nishida T, Hirota S, Yanagisawa A, Sugino Y, Minami M, Yamamura $Y$, et al. Clinical practice guidelines for gastrointestinal stromal tumor (GIST) in Japan: English version. Int J Clin Oncol 2008;13:416-30.

4. Downs-Kelly E, Rubin BP. Gastrointestinal stromal tumors: molecular mechanisms and targeted therapies. Patholog Res Int 2011;2011:708596. [CrossRef] 
5. Gold JS, Dematteo RP. Combined surgical and molecular therapy: the gastrointestinal stromal tumor model. Ann Surg 2006;244:17684. [CrossRef]

6. Connolly EM, Gaffney E, Reynolds JV. Gastrointestinal stromal tumours. Br J Surg 2003;90:1178-86. [CrossRef]

7. Zhou L, Liao Y, Wu J, Yang J, Zhang H, Wang X, et al. Small bowel gastrointestinal stromal tumor: a retrospective study of 32 cases at a single center and review of the literature. Ther Clin Risk Manag 2018;14:1467-81. [CrossRef]

8. Whang EE, Ashley SW, Zinner MJ. Small intestine. In: Brunicardi FC, Andersen D, Billiar T, Dunn D, Hunter J, Pollock RE, editors. Schwartz's Principles of Surgery. 8rd ed. New York: Mc Graw-Hill Comp; 2005. p. 1017-54.

9. Bölükbasi H, Nazli O, Tansug T, Bozdag AD, Isgiider AS, Yaman I, et al. Gastrointestinal stromal tumors (GISTs): analysis of 20 cases. Hepatogastroenterology 2006;53:385-8.

10. Piccinni G, Marzullo A, Angrisano A, Iacobone D, Nacchiero M. Endoscopic resection of benign very low-risk gastric gastrointestinal stromal tumors. Is it enough? Eur J Gastroenterol Hepatol 2007;19:177-9. [CrossRef]

11. Dizdar Ö, Güler N. Gastrointestinal Stromal Tümörler ve İmatinib Tedavisi. Hacettepe Tip Dergisi 2004;35:87-91.

12. Verde F, Hruban RH, Fishman EK. Small Bowel Gastrointestinal Stromal Tumors: Multidetector Computed Tomography Enhancement Pattern and Risk of Progression. J Comput Assist Tomogr 2017;41:407-11. [CrossRef]

13. Heinrich MC, Rubin BP, Longley BJ, Fletcher JA. Biology and genetic aspects of gastrointestinal stromal tumors: KIT activation and cytogenetic alterations. Hum Pathol 2002;33:484-95. [CrossRef]
14. Sturgeon C, Chejfec G, Espat NJ. Gastrointestinal stromal tumors: a spectrum of disease. Surg Oncol 2003;12:21-6. [CrossRef]

15. Onesti JK, McCahill LE. Gastrointestinal Stromal Tumors. In: Yeo CJ, Matthews JB, McFadden DW, Pemberton JH, Peters JH, editors. Shackelford's Surgery of the Alimentary Tract, Vol. 1, 7th edition. Philadelphia: Elsevier Saunders; 2013. p. 1028-34.

16. Heinrich MC, Corless CL, Demetri GD, Blanke CD, Von Mehren $\mathrm{M}$, Joensuu $\mathrm{H}$, et al. Kinase mutations and imatinib response in patients with metastatic gastrointestinal stromal tumor. J Clin Oncol 2003;21:4342-9. [CrossRef]

17. Dei Tos AP. The reappraisal of gastrointestinal stromal tumors: from Stout to the KIT revolution. Virchows Arch 2003;442:421-8.

18. Bucher P, Taylor S, Villiger P, Morel P, Brundler MA. Are there any prognostic factors for small intestinal stromal tumors? Am J Surg 2004;187:761-6. [CrossRef]

19. Kingham TP, DeMatteo RP. Multidisciplinary treatment of gastrointestinal stromal tumors. Surg Clin North Am 2009;89:217-33.

20. Nguyen SQ, Divino CM, Wang JL, Dikman SH. Laparoscopic management of gastrointestinal stromal tumors. Surg Endosc 2006;20:713-6.-6. [CrossRef]

21. Katoh T, Itoh Y, Mohri T, Suzuki H. Endoscopic enucleation of gastrointestinal stromal tumors of the stomach: report of five cases. World J Gastroenterol 2008;14:2609-11. [CrossRef]

22. Benjamin RS, Casali PG. Adjuvant Imatinib for GI Stromal Tumors: When and For How Long? J Clin Oncol 2016;34:215-8. [CrossRef]

23. Artigau Nieto E, Luna Aufroy A, Dalmau Pórtulas E, Rebasa Cladera P, Orellana Fernández R, Darnell Martín A, et al. Gastrointestinal stromal tumors: experience in 49 patients. Clin Transl Oncol 2006;8:594-8. [CrossRef]

\section{Mekanik Bağırsak Tıkanıklığına Sebep Olan Illeum Lokalizasyonlu Gastrointestinal Stromal Tümör: Olgu Sunumu}

Gastrointestinal stromal tümörler (GiST) özofagus, mide, ince bağırsak, kolon ve rektum gibi sindirim sistemi organlarından köken alan submukozal tümörlerdir. GiST’ler en sık midede (\%50-60), ikinci sıklıkta ince bağırsakta (\%20-25) ve daha az sıklıkta rektumda (5\%) görülürler. Genellikle gastrointestinal sistem hastalıklarının radyolojik görüntüleme ve endoskopik incelemelerinde veya gastrointestinal hemoraji, perforasyon veya tıkanıklık gibi acil durumların cerrahi tedavisi sırasında tesadüfen saptanmaktadır. GiST'lerin tanısını histopatolojik olarak koymak için cerrahi girişim ana yöntemdir. Cerrahi olarak rezeke edilebilir GiST’lerde cerrahi tedavideki birinci amaç, geride gözle görülebilir tümör bırakmayacak şekilde temiz cerrahi sınırların sağlandığı rezeksiyon işlemini uygulamaktır. Bu olgu sunumunda ileumda lokalize bir GiST olgusunun klinik görünümü, ameliyat öncesi tanısı ve tedavisi literatür verileri ışığında gözden geçirildi.

Anahtar Sözcükler: Akut karın; gastrointestinal stromal tümör; ince bağırsak obstrüksiyonu. 